\title{
THE CHICK EMBRYO CHORIOALLANTOIC MEMBRANE ASSAY AS A MODEL FOR THE STUDY OF ANGIOGENESIS
}

\author{
ENSAIO DA MEMBRANA CORIOALANTÓIDE DE EMBRIÃO DE GALINHA COMO \\ MODELO PARA O ESTUDO DA ANGIOGENNESE
}
Angélica Daiane Lemos do PRADO'; Elisa Flávia Luiz Cardoso BAILÃO²; João Carlos NABOUT ${ }^{2}$; Tatiana RABACHINI ${ }^{3}$; Paulo Roberto de MELO REIS ${ }^{4}$; Pablo José GONÇALVES ${ }^{5}$; Luciane Madureira ALMEIDA ${ }^{2 *}$

1. Mestre em Produção Vegetal da Universidade Estadual de Goiás, Ipameri - GO, Brasil. pradoadl@ hotmail.com; 2. Docentes do PPG RENAC da Universidade Estadual de Goiás, Câmpus Henrique Santillo, Anápolis, GO, Brasil; 3. Pesquisadora da University of Bern, Bern, Switzerland.-tatianarabachini@ hotmail.com; 4. Docente da Pontifícia Universidade Católica de Goiás - PUC, Goiânia, GO, Brasil; 5. Docente Instituto de Física da Universidade Federal de Goiás, Goiânia - GO, Brazil.

\begin{abstract}
Angiogenesis is a fundamental physiological process with strong implications in tissue homeostasis. Animal models helping to identify how angiogenesis is regulated are fundamental to answer many biological questions. Chick embryo chorioallantoic membrane (CAM) assay is one of the most employed methods to study angiogenesis. In this study we applied a scientometric approach to evaluate the employment of CAM assay in published articles. Temporal trends indicated that CAM assay was the preferred method to investigate angiogenesis over time. The publications had a significant number of citations and the impact factor of journals publishing articles is relevant for the scientific community. A total of 52 different research areas have articles published using this particular technique. Oncology is the research field in which CAM assay was mostly used. Accordingly, tumor-derived cell lines were the most frequent sample tested on CAM. We also identified that $73,6 \%$ of articles published used only CAM assay to answer questions concerning angiogenesis. We concluded that although the CAM assay is a classical approach, that does not need so much infrastructure and financial support to be performed, it is a well-accepted technique by the scientific community. In addition, this methodology has gain attention in scientific community because no pain is experienced by the chick and they are minor ethical concerns to employ this method. Moreover, this data can help researchers who are unfamiliar with the CAM assay to identify if this particular method is suitable for their research.
\end{abstract}

KEYWORDS: Alternative method. Angiogenesis. Bibliometric analysis. CAM assay. Oncology. Tumor vascularization.

\section{INTRODUCTION}

Angiogenesis is a complex biological process by which new blood vessels form from preexisting vascular tissue. At the most basic level, it involves proliferation, migration and differentiation of endothelial progenitor cells (FOLKMAN, 2003). Over many decades, extensive efforts have been made to develop therapeutic strategies to promote or to inhibit angiogenesis (FISHER et al., 2006), owing to its several medical applications. For example, a compound that is able to induce angiogenesis can be useful for tissue engineering, boosting cell proliferation and promoting wound healing (ALMEIDA et al., 2014). On the other hand, a compound that inhibits angiogenesis could be used to reduce the abnormal vasculature found in several types of solid tumors (RIBEIRO et al., 2012). In fact, millions of patients worldwide are being treated with compounds that regulate angiogenesis.
The use of animal models to investigate angiogenesis is critical for the development of therapeutic agents. Many have been described in the literature, including chick embryo chorioallantoic membrane (CAM) assays, corneal micropockets, Matrigel plugs, sponge matrix implants, rodent mesentery assays, disc angiogenic assays, and zebrafish models (NORRBY, 2006). Taking into account both the complexities of angiogenic reactions and the wide variations in tissue physiology, it is not possible to select only a single model for all angiogenic research. Each model has strengths and weaknesses; for example, some models are effective for screening therapeutic candidate compounds, while others are used in studies of dosage effects, molecular structureactivities, and synergistic effects of multiple agents on angiogenesis (NORRBY, 2006).

One of the most widely used models for the study of angiogenesis is the chick embryo chorioallantoic membrane (CAM) assay (NORRBY, 
2006). CAM is an extraembryonic membrane generated by the fusion of the chorion with the vascularized allantoic membrane (RIBATTI, 2010). It performs multiple functions during embryonic development, including respiration, calcium transport from the eggshell, acid-base homeostasis, and ion/water reabsorption from the allantoic fluid (YUAN et al., 2014). As the CAM expands, a rich vascular network is generated, allowing the quick and low-cost investigation of mechanisms underlying multiple biological processes, including tumor growth and metastasis, as well as pharmacological analysis of angiogenic and antiangiogenic compounds. One of the major advantages of the CAM model is the ability to directly observe angiogenic processes in live tissue in a dynamic manner.

CAMs can be cultured either in ovo, or ex ovo as a shell-less culture in Petri dishes or in a plastic wrap/cup apparatus (RIBATTI, 2010). In ovo, the chick egg provides a self-contained chamber that supports 21 days of development without artificial support media, special culture requirements, or storage facilities (KALIRAI et al., 2015). Moreover, chicken eggs are inexpensive and available in all seasons of the year. Another advantage is its relative transparency, allowing easy observation (KALIRAI et al., 2015). The CAM provides tissue responses similar to those of cellbased and animal-based assays (LOKMAN et al., 2012), with the advantage that CAM is not innervated and thus no pain can be experienced by the organism (MORENO-JIMÉNEZ et al., 2016). Moreover, because of its natural immunodeficiency, the CAM accepts transplantation from other species. Considering this, the CAM assay provides a rapid method to study angiogenesis in a well-developed vascular tissue (KUE et al., 2015) reliably, reproducibly, and inexpensively (NOWAKSLIWINSKA et al., 2014).

To evaluate the prevalence of CAM assays in published reports, we performed a bibliometric analysis, which is typically used to evaluate scientific production on a specified topic using counts and statistical analyses (ALMEIDA et al., 2015). In this study, we measured trends in the usage of CAM assays; the quality of the studies, estimated by number of citations and impact factor of the journals that publish papers including CAM assays; the main areas and journals interested in this method; the types of samples tested; the exclusivity of CAM assay, as a model to evaluate angiogenesis, on experimental design; the frequency of use of CAM assays relative to the use of competing models; the variations of CAM assays; and the level of collaboration patterns between countries. Our results indicate that CAM assay is widely used and highly accepted as a reliable method to study angiogenesis.

\section{MATERIAL AND METHODS}

\section{Data collection}

Data were obtained from Thomson-Reuters database (Web of Science platform) from 1991 to 2018. Initial date was defined based on abstract availability on database. Final data was defined as the last full year with data available since this study began. We divided the production of papers each year by the overall production of papers (obtained in ISI) to eliminate the effect of the temporal increase in papers (NABOUT et al., 2012). The impact factor of different journals was collected in February 2018 on the Journal Citation Reports (JCR), published by the Institute for Scientific Information (ISI) and edited by Thomson, exclusively to evaluate indexed papers in the Web of Science platform.

\section{Search criteria}

The combination of the following words was used: (1) "chorioallantoic membrane" and CAM or (2) "chorioallantoic membrane" or (3) "chick embryo membrane", which could be in the title, abstract, or in the list of keywords. The analysis were conducted to obtain the following information from each paper: (1) year of publication; (2) number of citations; (3) name of the journal and its impact factor; (4) area of study using the CAM assay; (5) if the tested substance was an animal tissue/cell, a new drug, a plant extract/compound, an inorganic compound, a nanoparticle, or other; (6) other methods used to evaluate angiogenesis in combination with CAM assays; (7) temporal trends of other angiogenesis models relative to CAM assays; (8) variations of CAM technique; (9) countries of publication and average authorship; and (10) mapping of countries of research groups interested in the technique and their international research networks.

\section{Data Analysis}

Pearson correlation was used to estimate the frequency of papers using CAM assay in relation to the total number of articles published in ISI by year to evaluate the increase of the use of CAM technique over time. The significance value was obtained through the Monte Carlo test with 999 randomizations (CZERWON, 1990). We considered significant $\mathrm{p}$ values $<0.05$. This analysis was conducted using "R 3.2.2 program" (R CORE 
TEAM, 2003). Other parameters analyzed were evaluated using basic descriptive statistics.

\section{International Networks}

To evaluate international networks, we used two approaches: an analysis of all countries with which authors were associated and an analysis of 30 leading countries based on their number of papers. For both approaches, we identified the country of each author listed in the paper, generating an adjacency matrix indicating the number of collaborative papers for each pair of countries. The importance of each country was estimated by the degree of centrality (DC). The DC of the country $i$ (DCi) is a measure of the number of links (edges) that each country has. The DCi was divided by number of countries minus one to calculate the relative degree centrality (RDCi) of country $i$, which was used to evaluate the importance of countries on the basis of the sizes of their respective vertices in network graphs (KOSCHÜTZKI et al., 2005). The analysis of such networks has been used in bibliometric studies. This analysis indicated the scientific production for each country and the level of collaboration among countries. These data should have utility for scientific management.

Temporal trends of CAM assay preference in comparison to other in vivo angiogenesis models
To compare the tendencies in CAM assay application in relation to others in vivo angiogenic models, we search for the following terms in Web of Science platform: (1) "corneal micropocket"; (2) "sponge implant" or "matrix implant"; (3) "matrigel plug assay"; and (4) "disc angiogenesis assay". Those words could be in the title, abstract, or in the list of keywords.

\section{RESULTS AND DISCUSSION}

\section{Quality indicators of papers involving CAM assay}

Our analysis identified a total of 2,248 research articles that used CAM assay to address multiple biological questions. We observed that the number of publications using this method increased constantly and significantly $(r=0.96, p<0.001)$ over the years (Fig. 1a). The publications had a significant number of citations (Fig. 1b) and the impact factor of journals publishing articles using this technique is relevant for the scientific community (Fig. 1c, d). Our results using multiple bibliometrics approaches indicate a continuous increase in the number and the maintenance of the quality of articles that have used CAM assay to address biological question.
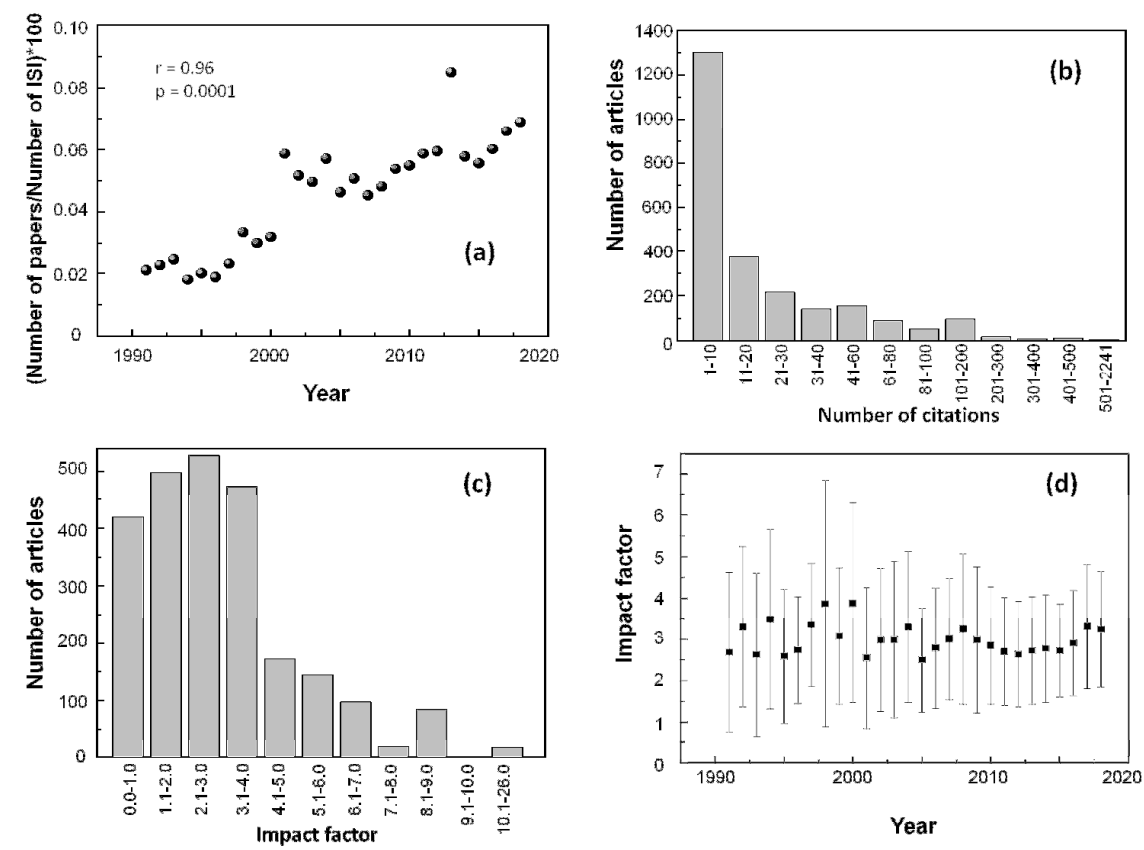

Figure 1. Bibliometric information of the articles using CAM assay: (a) number of publications per year; (b) frequency of citations per article; (c) journal's impact factor; (d) mean impact factor $( \pm \mathrm{SD})$ of journals publishing articles using CAM assay. 
Temporal trends indicate that more than a hundred articles using CAM assay were published per year in the last decade. This result may reflect the fact that this particular technique display several advantages such as (a) rapid growth of the embryo choriollantoic membrane, providing faster results; (b) low-cost; (c) simplicity; (d) high reproducibility; (e) easy dynamic observation; (f) immunodeficient environment; $(\mathrm{g})$ high-probability of tumor cell grafting due to CAM intense vascularization and finally (h) minor ethical concerns (NOWAKSLIWINSKA et al., 2014; ALEKSANDROWICZ; HERR, 2015). Still, some disadvantages are also considered and discussed in the literature. Among them we can include (a) difficulty in observing new vessels; (b) difficulty in distinguishing manipulation effects from the effects related to the tested compound; (c) nonspecific inflammatory reaction; (d) presence of perivascular inflammatory infiltrate together with any hyperplastic reaction of the chorionic epithelium; (e) not being a mammalian model; (f) drugs that require metabolic activation can not be assessed; (g) very sensitive to an increase in oxygen tension (NORRBY, 2006; RIBATTI, 2010; RIBATTI, 2014).

It is well established that the number of citations is an important tool to evaluate the impact of a particular work in the scientific community (CARNEIRO et al., 2008). In our study, we observed that the number of citations of the papers varied from zero to 2,241. However, more than half of the articles analyzed were cited 10-20 times (Fig 1b). This observation is consistent with common bibliometric patterns (CARNEIRO et al., 2008). One article in particular received 2,241 citations and described the application of a CAM assay to study the requirement of Vascular Integrin Alpha(V) Beta(3) for angiogenesis (BROOKS et al., 1994).

The importance of a journal can be measured by the traditional Journal Impact Factor (IF) (NANSEN; MEIKLE, 2014). Here, the IF of journals publishing articles using CAM assay ranged from zero to 26 , with maximum frequency amid 2.1 to 3.0 (Fig 1c). In general, the mean IF of the journals publishing articles that used CAM assay was close to 3.0 along the years (Fig 1d). This result indicates that CAM assays is are used by several multiple applications and there is are no significant no biases regarding the use of this particular methodology to address specific biological questions in relation to the relevance of the article published.

\section{Research areas using CAM assay}

Our analysis revealed that CAM assays were used in 52 different scientific areas, as defined on the ISI database. Considering only the 15 most cited areas (Fig 2a), oncology was the area with the highest number of articles using CAM assays. A total of 514 articles were published in this field. The reason behind this popularity is because angiogenesis plays a major role in tumor development and maintenance (CIMPEAN et al., 2008). Relative to standard mouse models, in which tumor growth takes between 3 to 6 weeks, xenograft tumors generated in chick CAMs grow to visible size between 2 and 5 days after cell transference (RIBATTI, 2014). As noted above, the natural immunodeficiency of this membrane allows the transplantation from various tissues and species to the CAM; consequently, different tumor-derived cell lines have been seeded on CAM to study multiple aspects of tumor biology (RIBATTI, 2010). Once tumor cells are seeded on CAM, they can provide valuable information regarding tumor cell adherence, invasion of the mesenchyme underlying the blood vessels, tumor cell survival in the circulation, anchorage, penetration, and proliferation in distant organs (RIBATTI, 2014). For this reason, CAM models have been extensively used in studies investigating the role of angiogenesis in tumor biology. Several articles describe the use of this method to answer questions about ovarian cancer breast cancer (GAUTAM et al., 2016), cervical cancer (ZHOU et al., 2015), glioblastoma (FÖRNVIK et al., 2016), gallbladder cancer (SUDAM PATIL et al., 2016), pancreatic cancer (ROVITHI et al., 2017), renal cancer (FERICIAN et al., 2015) and hepatocellular carcinoma (LV et al., 2016; HAN et al., 2016). 

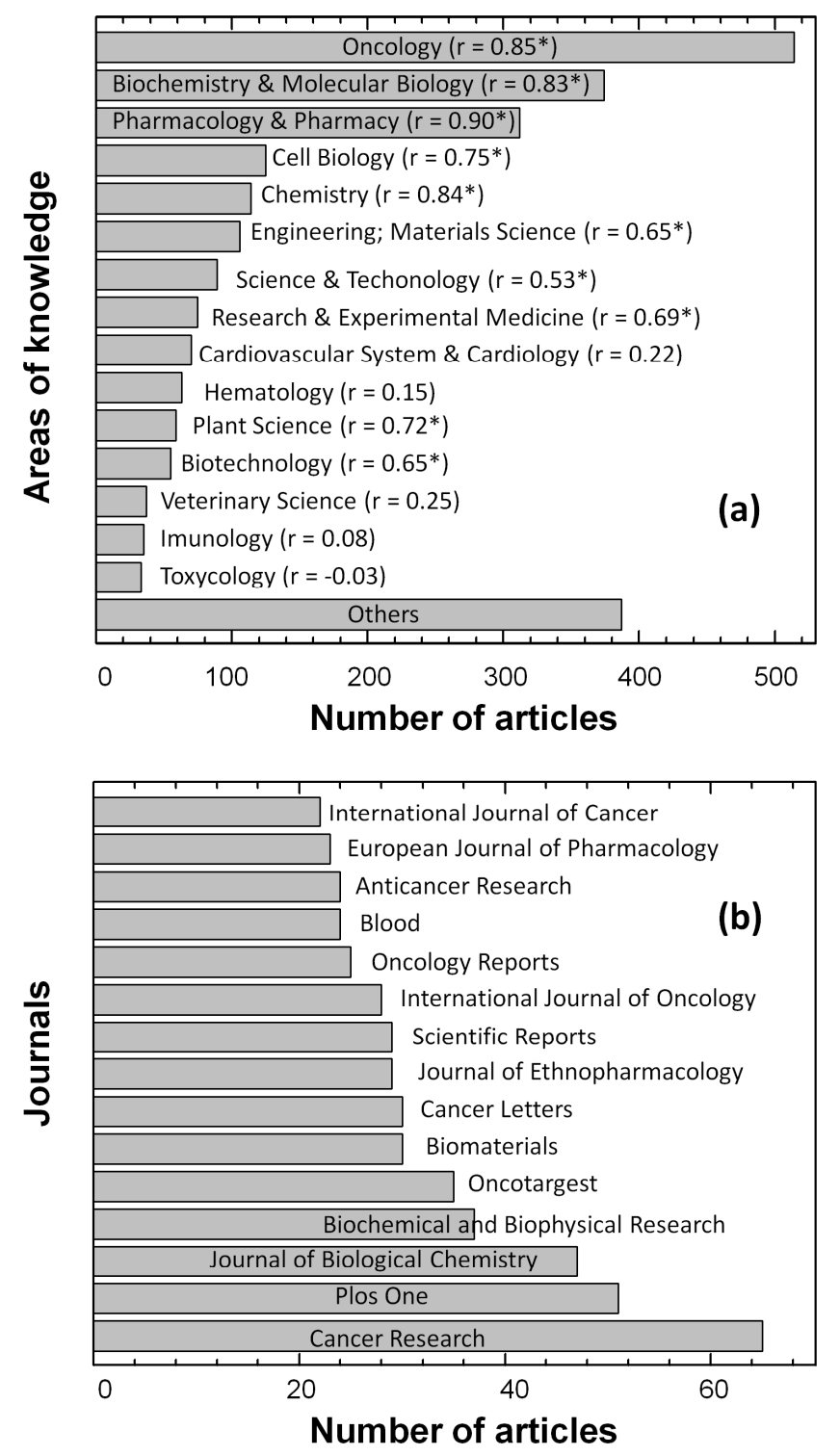

Figure 2. Research areas and journals interested about CAM assay. (a) Main areas of knownledge that publish using CAM assay; and (b) main journals interested on papers that used CAM assay.

CAM assay has also been used in Pharmacology and Pharmacy to evaluate the angiogenic and anti-angiogenic potential of specific drugs. As an example we can mention the use of CAM to test the angiogenic potential of resveratrol methylated derivatives (CHEN et al., 2016) and the use this technique to test the anti-angiogenic potential of curcumin-capped copper nanoparticles (KAMBLE et al., 2016).

For Engineering and Material Science, CAM is applied as a method to evaluate angiogenesis in tissue reconstruction (ISHIDA; MITSUI, 2016). Unlike other in vivo models, such as the murine subcutaneous implant, CAM assay is minimally invasive to the chick embryo and hence, considered a refinement model for animal research (KUE et al., 2015). Many studies have used CAM to evaluate tissue repair including studies about osteogenesis (YAN et al., 2016), myocardial regeneration (FANTON et al., 2016) and even induction of angiogenesis using polymer-based constructs (KANCZLER et al., 2007). We also analyzed the acceptability of the CAM assay over the time (Fig 2a). For this analysis we verified the use of this methodology regarding research field. Our results indicate that CAM is a reliable method to answer several biological questions, with positive ' $r$ ' values found for all fields, with exception of 
toxicology. For this particular field, researchers preferred other methods to answer their hypothesis, such as skin and eye irritation assays (NOWAKSLIWINSKA et al., 2014).

The areas of knowledge identified in the present search were a reflection of journals in which the articles were published. Figure $2 b$ shows the journals with more than 20 publications that have included CAM assays. A total of 768 different journals published such articles. Cancer Research, from the American Association of Cancer Research had 65, followed by PLoS One with 51, and the Journal of Biological Chemistry from the 'American Society for Biochemistry and Molecular Biology, with 47 articles. Among the journals publishing articles using CAM assays, the impact factor ranged from 2.8 to 9.1. This result reflects that the assay is used in articles with high acceptability. It also indicates a wide diversity of journals publishing articles using this methodology.

\section{Applications of CAM assay}

CAM assay have been widely used because of its several advantages (LOKMAN et al., 2012). To elucidate for which particular application CAM method was used, we have stratified articles according to the origin of the main samples tested using CAM. Six categories were created: (a) animal tissues/cells, (b) new drugs, (c) vegetable extracts or bioactive compounds, (d) inorganic compounds, (e) nanoparticles and others. Our results show that a total of $1,326(54.2 \%)$ articles have used CAM to assay animal/tissue samples (Fig 3). The most common samples tested were tumor-derived cell lines, such as neuroblastoma and glioblastoma (KLAGSBRUN et al., 1976); head and neck squamous cell carcinoma (GRONAU et al., 2006); human colorectal cancer (SUBAUSTE et al., 2009); osteosarcoma (BALKE et al., 2010); human ovarian carcinoma (ADAR et al., 2012); and human hepatocellular carcinoma (LV et al., 2016). A total of $378(15.4 \%)$ used CAM to evaluate the angiogenic and the anti-antiogenic potential of specific drugs (Fig 3). As an example of drugs tested using CAM we can mention agkistin (YEAH et al., 2000); heparin (CASU et al., 2002); curcumin (HAHM et al., 2004); emolin (KWAK et al., 2006); and azaspirine (ASAMI et al., 2008). The use of CAM to test vegetable extracts/ bioactive plant compounds was observed in 317 (12.9\%) articles (Fig 3). Some of these compounds include root methanol extract from Calliandra portoricensis (ADARAMOYE et al., 2015); crude saponis of Rumex hastatus (AHMAD et al., 2016); Hancornia speciosa latex (ALMEIDA et al., 2014) among others. Finally, we also identified that 193 (7.9\%) of articles used CAM method to test inorganic compounds and $89(3,9 \%)$ used it to test nanoparticles (Fig 3). The main goal of these articles was to evaluate if the tested compound could be used in implants (GOMES et al., 2016); or to verify if the sample tested was toxic (AHMAD et al., 2016); or if the compound could promote tumor angiogenesis (KAMBLE et al., 2016). Then, our data indicate that CAM assay is widely used, but seems to be more often seen in articles aiming to investigate biological questions linked to cancer research.

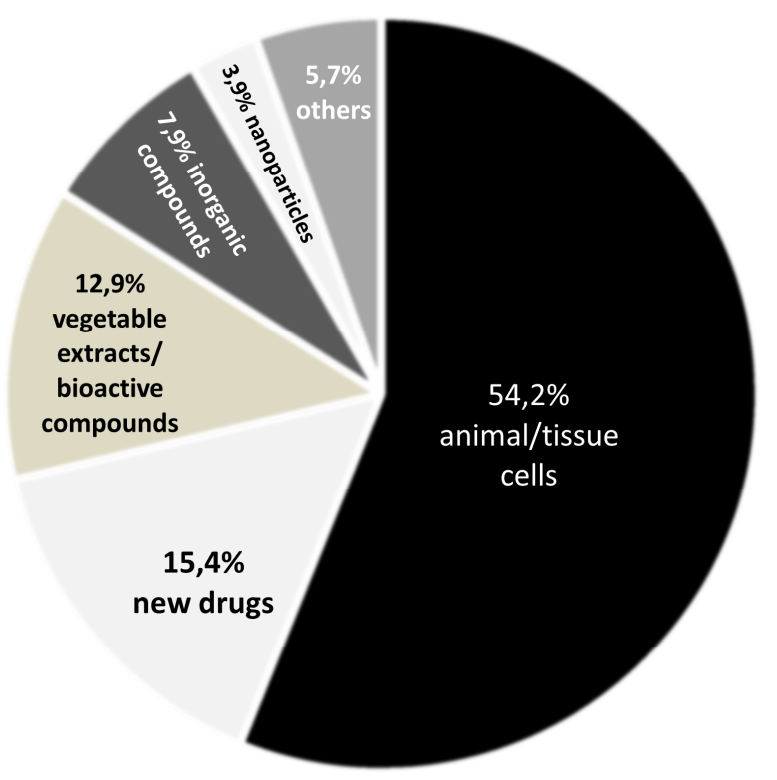

Figure 3. Frequency of articles published using different types of samples in CAM assay. 


\section{Using CAM assay as a single model to investigate angiogenesis}

Our data also show that $73,6 \%$ of articles published have used only CAM to investigate angiogenesis. This result indicates that CAM assay is a reliable method to answer a particular biological problem. Articles that have another methodology to further confirm CAM assay results, opted to use xenograft in nude mice (FÖRNVIK et al., 2016; THANEKAR et al., 2016). Corneal micropoket assay, sponge implant, disc angiogenesis systems, matrigel plug assay, zebrafish assay, rodent mesentery angiogenesis assay and direct in vivo angiogenesis could also be used as angiogenesis models (NORRBY, 2006).

\section{Temporal trends of CAM assay use in} comparison to other in vivo angiogenesis models

In vivo angiogenesis was evaluated in 2,248 articles using the CAM assay; in 643 articles using matrigel plug assay; in 89 articles using corneal micropocket assay; in 71 articles using sponge matrix implant assay; and in 17 articles using disc angiogenic assay (Table 1). This result indicates that there is a strong preference for choosing CAM assay to test angiogenesis among researchers. Temporal trends also indicate that CAM and matrigel plug methodologies were constantly and significantly applied over the years to investigate angiogenesis, as indicated by ' $r$ ' values (Table 1). Sponge matrix implant and corneal micropoket also have a positive tendency over the years, but less prominent than CAM or matrigel plug assay. Interestingly, we could observe that the employment of disc angiogenic assay has decreased over the years. This result may reflect the fact that this particular method is not frequently applied to study solid tumors (NORRBY, 2006). These results are important to understand that any method used to investigate angiogensesis have advantages and disadvantages. Ideally, the following criteria should be considered before choosing a specific method to answer a particular question in angiogenesis: (a) the assay should provide a quantitative measure of the new vascular network; (b) dose response curves should be created in order to determine concentration, liberation rate and time of treatment of the tested compound; (c) if tumor-derived cell lines are used as a source of angiogenic factors, they should be genetically well defined; (d) there should be a clear distinction between newly formed and pre-existing host vessels; (e) the response seen in vitro should be confirmed in vivo; (f) tissue damage should be avoided, since it may lead to formation of new vessels; ( $\mathrm{g}$ ) the assay should permit long-term and, if possible, noninvasive monitoring; and (h) it should be cost-effective, rapid, easy to set up, reproducible and reliable (NORRBY, 2006).

Table 1. Bibliometric information of the articles related to different in vivo angiogenic models: matrigel plug assay, corneal micropocket, sponge matrix implant, disc angiogenic assay and CAM.

\begin{tabular}{|c|c|c|}
\hline In vivo angiogenesis model & Number of articles & Pearson correlation \\
\hline $\begin{array}{l}\text { Chick embryo chorioallantoic membrane } \\
\text { (CAM) }\end{array}$ & 2,248 & $0.95 *$ \\
\hline Matrigel plug & 643 & $0.89 *$ \\
\hline Corneal micropocket & 89 & 0.22 \\
\hline Sponge matrix implant & 71 & 0.59 \\
\hline Disc angiogenic assay & 17 & 0.24 \\
\hline
\end{tabular}

Disc angiogenic assay

\section{Variations of CAM assay}

Several protocols are available to perform CAM assay and the most commonly employed are in ovo, ex ovo and Het-CAM. To perform the assay using the in ovo protocol is necessary to open a circular hole on the eggshell to expose the CAM. With this protocol it is possible to achieve a more preserved physiological environment, as well as allow the development of the long-term embryo. It is also the protocol of choice found in the vast majority of articles published, with a total of 2,273 studies using this technique. In the ex ovo assay the embryo is removed from the egg and transferred to a petri dish. We scored only 68 articles using this method. The main disadvantage of this procedure is related to the low survival rate of the embryo during the process. Most of the time, removing the embryo from the eggshell can damage the yolk membrane (NOWAK-SLIWINSKA et al., 2014). On the other hand, the ex ovo method facilitates the testing of a larger number of samples and also improves quantification once a larger area of the CAM can be exposed and quantified (RIBATTI, 2016). Alternatively, the Het-CAM is the method of choice when the irritation potential of a substance needs to be addressed. We identified 107 articles using this particular technique. Since the Interagency Coordinating Committee on the Validation of 
Alternative Methods (ICCVAM) considers Het$\mathrm{CAM}$ as an alternative method for conjunctive irritation testing, HET-CAM has been extensively used for this purpose.

\section{Publications by country, average authorship and} collaborative network

We next sought to investigate if there was any trend of CAM assay use in relation to the country in which the research was conducted. The country of the corresponding author was chosen as the identification criterion. A total of 392 articles $(16.0 \%)$ were published by authors from China, followed by 387 articles (15.8\%) published by authors from the USA, and $196(8.0 \%)$ articles published by authors from Germany (Fig 4A). As expected, this result reflects the fact that the scientific production of nations is related to the socio-economic characteristics of the country [2]. Moreover, this pattern also is frequently observed in other bibliometric studies (for example, ALMEIDA et al. 2015), and demonstrates the influence of research funding on scientific production and collaboration. It is important to note that although CAM assay is a simple and old approach, it has still
PRADO, A. D. L. et al.

been frequently used for researchers from countries with the most modern infrastructure, such as the USA, Germany, and China.

Research cooperation was evaluated by the average of the number of authors (Fig 4B) and the collaboration networks (Fig 5). As observed, most of the articles had 5 to 8 authors. Only 7 articles were written by a single author. According to NABOUT et al. (2015), there is a natural trend showing a decrease in the number of articles produced by a single author over the years for all areas of biology. Our results also show that from the 65 countries that published articles using CAM, only 33 involved international collaborations (Fig 5). The USA, England, and Germany were the countries with the highest number of international collaborations. Although international collaboration networks were not common in papers using CAM assays to assess angiogenesis, it encourages researchers to collaborate in order to increase productivity and to promote better application of financial resources, as noted by Lee and Bozeman (2005) and supported by Subramanyam, who have shown that international scientific collaboration has increased in volume and importance over the years.
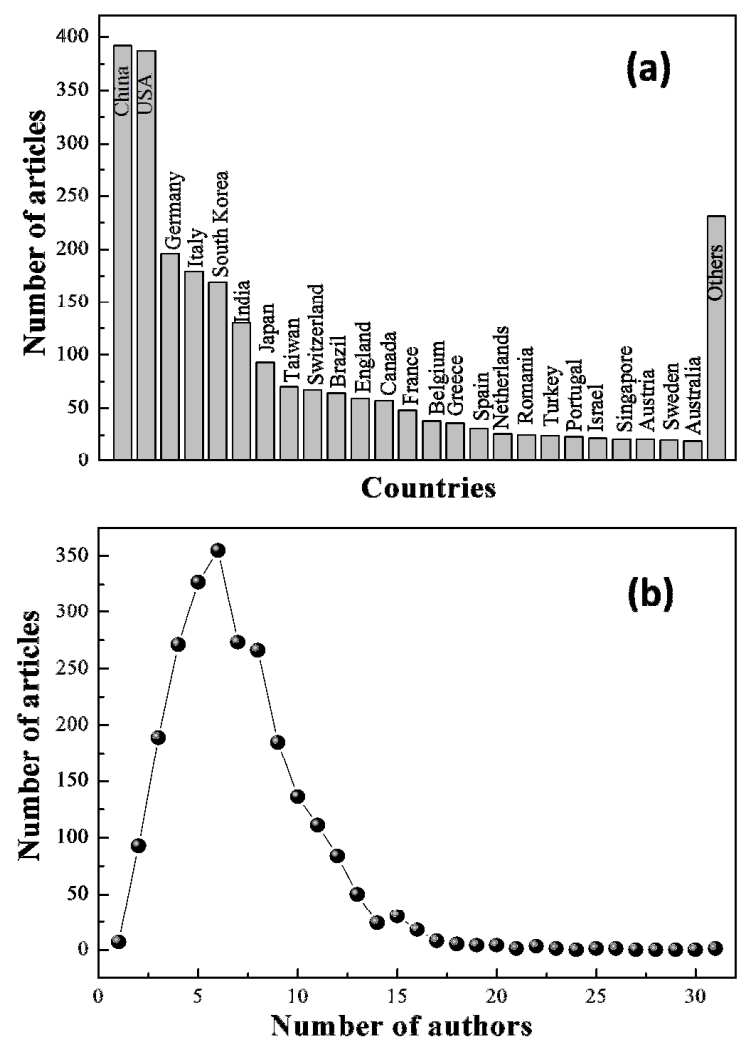

Figure 4. Analysis of author geographic distributions and collaboration network: A) shows the number of publish items per country (using data from corresponding author); B) shows the average authorship per year. 


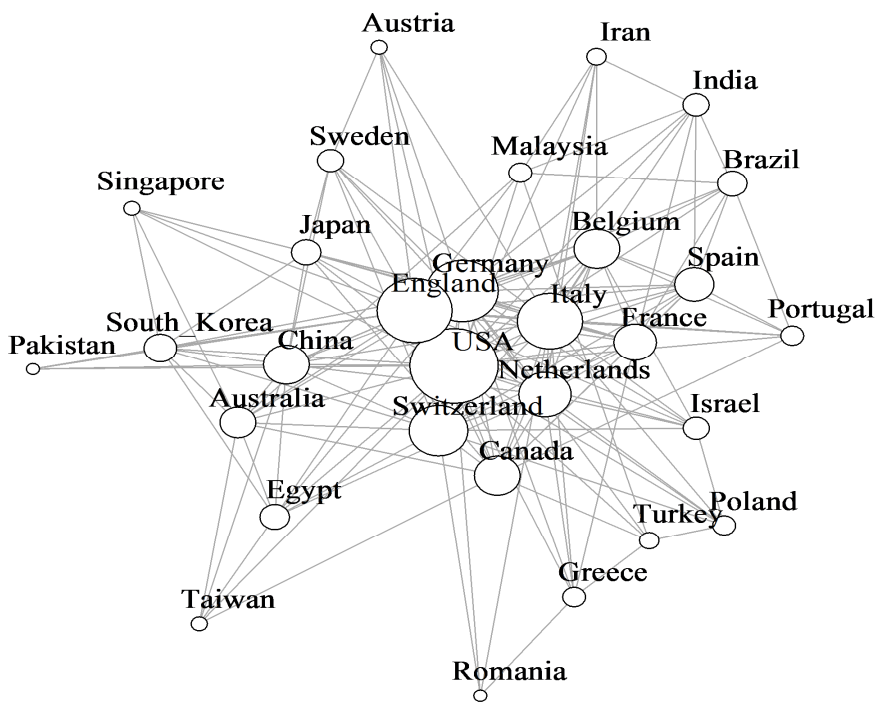

Figure 5: Network of the 30 countries with great number of international collaborations.

\section{CONCLUSIONS}

This study reported that CAM is a reliable and highly employed method to assess angiogenesis around the world. During 1991 till 2018, a total of 2,248 articles belonging to 52 different areas of knowledge have used CAM assay to address a specific biological question. The field of research in which CAM assay was most used was oncology, especially to evaluate the effect of tumor-derived cell lines influence in angiogenesis. The scienciometric approaches showed a continuous increase of both quantitative (number article per year) and qualitative (IF; article citations) metrics on literature reporting the utilization of the CAM assay. We concluded that although the CAM assay is a classical approach, that does not need so much infrastructure and financial support to be performed, it is a well-accepted technique by the scientific community. We believe that in the next years the use of the CAM assay will grow up since the discussion about the use of alternative methods to animal testing is getting stronger. Altogether, the results presented in this article can help researchers who are unfamiliar with the CAM assay to elucidate how this technique can help to answer questions related to angiogenesis.

\section{ACKNOWLEDGEMENTS}

LMA, EFLCB were supported by Universidade Estadual de Goiás with fellowships at the program PROBIP (Scientific Production Support Program); JCN and PJG were supported by CNPq productivity fellowships and ADLP was supported by CAPES student fellowship.

RESUMO: A angiogênese é um processo fisiológico fundamental com fortes implicações na homeostase tecidual. Modelos animais que ajudam a entender como a angiogênese é regulada, são fundamentais para responder a muitas questões biológicas. O ensaio de membrana corioalantóide de embrião de galinha (CAM) é um dos métodos mais empregados para estudar a angiogênese. Neste estudo foi aplicada uma abordagem cientométrica para avaliar o emprego do ensaio CAM em artigos científicos já publicados. Tendências temporais indicaram que o ensaio CAM foi o método mais usado para investigar a angiogênese ao longo do tempo. Os artigos científicos que usaram a metodologia CAM foram publicados em periódicos com significativos números de citações e fator de impacto. No total 52 diferentes áreas de conhecimento usaram a técnica CAM, sendo a oncologia o campo o qual produziu maior número de artigos usando essa metodologia. Consequentemente o material biológico mais testado foi as linhagens celulares tumorais. Também foi identificado que $73,6 \%$ dos artigos publicados utilizaram apenas o teste CAM para responder questões relacionadas à angiogênese. Pode se concluir que embora o ensaio CAM seja uma abordagem clássica, que não necessita de muita infraestrutura e apoio financeiro para ser realizado, é uma técnica bem aceita pela comunidade científica. Além disso, esta metodologia tem ganhado atenção na comunidade científica porque os animais testados não sofrem dor e por essa razão esse modelo experimental exige mínimas preocupações éticas. 
Além disso, esses dados podem ajudar os pesquisadores que não estão familiarizados com o ensaio CAM a identificar se esse método específico é adequado para sua pesquisa.

PALAVRAS-CHAVE: Métodos alternativos. Angiogenese. Análise bibliométrica. Ensaio CAM. Oncologia. Vascularização tumoral.

\section{REFERENCES}

ADAR, Y.; STARK, M.; BRAM, E. E.; NOWAK-SLIWINSKA, P.; VAN DEN BERGH, H.; SZEWCZYK, G.; SARNA, T.; SKLADANOWSKI, A.; GRIFFIOEN, A. W.; ASSARAF, Y. G. Imidazoacridinonedependent lysosomal photodestruction: A pharmacological Trojan horse approach to eradicate multidrugresistant cancers. Cell Death Dis. v. 3, e293-10, 2012. https://doi.org/10.1038/cddis.2012.30

ADARAMOYE, O.; ERGUEN, B.; OYEBODE, O.; NITZSCHE, B.; HÖPFNER, M.; JUNG, K.; RABIEN, A. Antioxidant, antiangiogenic and antiproliferative activities of root methanol extract of Calliandra portoricensis in human prostate cancer cells. J. Integr. Med. v. 13, p. 185-193, 2015. https://doi.org/10.1016/S20954964(15)60175-3

AHMAD, K. A.; MOHAMMED, A. S.; ABAS, F. Chitosan nanoparticles as carriers for the delivery of FKAZ14 bacteriophage for oral biological control of colibacillosis in chickens. Molecules, v. 21, 2016. https://doi.org/10.3390/molecules21030256

ALEKSANDROWICZ, E.; HERR, I. Ethical euthanasia and short-term anesthesia of the chick embryo. ALTEX, v. 32, p. 143-147, 2015. https://doi.org/10.14573/altex.1410031

ALMEIDA, L. M.; FLORIANO, J. F.; RIBEIRO, T. P.; MAGNO, L. N.; DA MOTA, L. S. L. S.; PEIXOTO, N.; MRUÉ, F.; MELO-REIS, P.; LINO, R. D. S.; GRAEFF, C. F. D. O.; GONÇALVES, P. J. Hancornia speciosa latex for biomedical applications: Physical and chemical properties, biocompatibility assessment and angiogenic activity. J. Mater. Sci. Mater. Med. v. 25, p. 2153-2162, 2014. https://doi.org/10.1007/s10856$014-5255-8$

ALMEIDA, L. M., PRADO, A. D. L., D’ABADIA, P. L., MACHADO, K. B., MELO-REIS, P. R., NABOUT, J. C., GONÇALVES, P. J. The state-of-art in angiogenic properties of latex from different plant species. Cur Angiogenesis v. 4, p. 10-23. 2015. doi:10.2174/221155280401160517164531

ASAMI, Y.; KAKEY, A. H.; KOMI, Y.; KOJIMA, S.; NISHIKAWA, K.; BEEBE, K.; NECKERS, L.; OSADA, H. Azaspirine, a fungal product, inhibits angiogenesis by blocking Raf-1 activation. Cancer Sci, v. 99, p. 1853-1858, 2008. doi:10.1111/j.1349-7006.2008.00890.

BALKE, M.; NEUMANN, A.; KERSTING, C.; AGELOPOULOS, K.; GEBERT, C.; GOSHEGER, G.; BUERGER, H.; HAGEDORN, M. Morphologic characterization of osteosarcoma growth on the chick chorioallantoic membrane. BMC Res. Notes, v. 3, 2010. https://doi.org/10.1186/1756-0500-3-58

BROOKS, P. C.; CLARCK, R. A. F.; CHERESH, D. A. Requirement of Vascular Integrin alpha(V)beta(3) for Angiogenesis. Science, v. 80, n. 264, p. 569-571, 1994. https://doi.org/DOI: 10.1126/science.7512751

CARNEIRO, F. M.; NABOUT, J. C.; BINI, L.M. Trends in the scientific literature on phytoplankton. Limnology v. 9, p. 153-158, 2008. https://doi.org/10.1007/s10201-008-0242-8

CASU, B.; GUERRINI, M.; NAGGI, A.; PEREZ, M.; TORRI, G.; RIBATTI, D.; CARMINATI, P.; GIANNINI, G.; PENCO, S.; PISANO, C.; BELLERI, M.; RUSNATI, M.; PRESTA, M. Short heparin sequences spaced by glycol-split uronate residues are antagonists of Fibroblast Growth Factor 2 and angiogenesis inhibitors. Biochemistry, v. 41, p. 10519-10528, 2002. https://doi.org/10.1021/bi020118n 
CHEN, Z. Q.; ZHANG, L.; YU, J. T.; CHEN, L. K.; ZHOU, B. Identification of resveratrol derivative $3,3^{\prime}, 4,4^{\prime}, 5,5^{\prime}$-hexamethoxy- trans-stilbene as a novel pro-angiogenic small-molecule compound. Eur. J. Pharmacol. v. 791, p. 185-194, 2016. https://doi.org/10.1016/j.ejphar.2016.08.034

CIMPEAN, A.M., RIBATTI, D., RAICA, M. The chick embryo chorioallantoic membrane as a model to study tumor metastasis. Angiogenesis, v. 11, p. 311-319, 2008. https://doi.org/10.1007/s10456-008-9117-1

CZERWON, H.J. Scientometric indicators for a specialty in theoretical high-energy physics: Monte Carlo methods in lattice field theory. Scientometrics, v. 18, p. 5-20, 1990. https://doi.org/10.1007/BF02019159

FANTON, Y.; HOUBRECHTS, C.; WILLEMS, L.; DANIELS, A.; LINSEN, L.; RATAJCZAK, J.; BRONCKAERS, A.; LAMBRICHTS, I.; DECLERCQ, J.; RUMMENS, J.L.; HENDRIKX, M.; HENSEN K. Cardiac atrial appendage stem cells promote angiogenesis in vitro and in vivo. J Mol Cell Cardiol., v. 97, p. 235-244, 2016. https://doi.org/10.1016/j.yjmcc.2016.06.005

FERICIAN, O.; CIMPEAN, A.M.; AVRAM, S.; RAICA, M. Endostatin effects on tumor cells and vascular network of human renal cell carcinoma implanted on chick embryo chorioallantoic membrane. Anticancer Res., v. 35, p. 6521-6528, 2015.

FISHER, C.; SCHNEIDER, M.; CARMELIET, P. Principles and therapeutic implications of angiogenesis vasculogenesis and arteriogenesis. Handb Exp Pharmacol (176 Pt2): 157-212, Springer-Verlag Berlin Heidelberg, 2006.

FOLKMAN, J. Fundamental concepts of the angiogenic process. Curr. Mol. Med., v. 3, p. 643-51, 2003. https://doi.org/10.2174/1566524033479465

FÖRNVIK, K.; ZOLFAGHARI, S.; SALFORD, L.G.; REDEBRANDT, H.N. ITPP Treatment of RG2 Glioblastoma in a Rat Model. Anticancer Res., v. 36, p. 5751-5756, 2016.

https://doi.org/10.21873/anticanres.11158

GAUTAM, J.; BANSKOTA, S.; REGMI, S.C.; AHN, S.; JEON, Y.H.; JEONG, H.; KIM, S.J.; NAM, T. GYU, JEONG, B.S.; KIM, J.A. Tryptophan hydroxylase 1 and 5-HT7receptor preferentially expressed in triplenegative breast cancer promote cancer progression through autocrine serotonin signaling. Mol. Cancer, v. 15, p. 1-14, 2016. https://doi.org/10.1186/s12943-016-0559-6

GOMES, P.S.; ZOMORODIAN, A.; KWIATKOWSKI, L.; LUTZE, R.; BALKOWIEC, A.; COLACO, B.; PINHEIRO, V.; FERNANDES, J.C.S.; MONTEMOR, M.F.; FERNANDES, M.H. 2016. In vivo assessment of a new multifunctional coating architecture for improved $\mathrm{Mg}$ alloy biocompatibility. Biomed. Mater. v. 11. https://doi.org/10.1088/1748-6041/11/4/045007

GRONAU, S.; THESS, B.; RIECHELMANN, H.; FISCHER, Y.; SCHMITT, A.; SCHMITT, M. An autologous system for culturing head and neck squamous cell carcinomas for the assessment of cellular therapies on the chorioallantois membrane. Eur. Arch. Oto-Rhino-Laryngology, v. 263, p. 308-312, 2006. https://doi.org/10.1007/s00405-005-1008-0

HAHM, E.R.; GHO, Y.S.; PARK, S.; PARK, C.; KIM, K.W.; YANG, C.H. Synthetic curcumin analogs inhibit activator protein-1 transcription and tumor-induced angiogenesis. Biochem. Biophys. Res. Commun., v. 321, p. 337-344, 2004. https://doi.org/10.1016/j.bbrc.2004.06.119

HAN, S.Y.; HAN, H.B.; TIAN, X.Y.; SUN, H.; XUE, D.; ZHAO, C.; JIANG, S.T.; HE, X.R.; ZHENG, W.X.; WANG, J.; PANG, L.N.; LI, X.H.; LI, P.P. MicroRNA-33a-3p suppresses cell migration and invasion by directly targeting PBX3 in human hepatocellular carcinoma. Oncotarget, v. 7, p. 42461-42473, 2016. https://doi.org/10.18632/oncotarget.9886 
ISHIDA, K.; MITSUI, T. Generation of bioengineered feather buds on a reconstructed chick skin from dissociated epithelial and mesenchymal cells. Dev. Growth Differ., v. 58, p. 303-314, 2016. https://doi.org/10.1111/dgd.12275

KALIRAI, H.; SHAHIDIPOUR, H.; COUPLAND, S.E.; LUYTEN, G. Use of the Chick Embryo Model in Uveal Melanoma. Ocul. Oncol. Pathol., v. 1, p. 133-140, 2015. https://doi.org/10.1159/000370151

KAMBLE, S.; UTAGE, B.; MOGLE, P.; KAMBLE, R.; HESE, S.; DAWANE, B.; GACCHE, R. Evaluation of curcumin capped copper nanoparticles as possible inhibitors of human breast cancer cells and angiogenesis: a comparative study with native curcumin. AAPS PharmSciTech, v. 17, p. 1030-1041, 2016. https://doi.org/10.1208/s12249-015-0435-5

KANCZLER, J.M.; BARRY, J.; GINTY, P.; HOWDLE, S.M.; SHAKESHEFF, K.M.; OREFFO, R.O.C. Supercritical carbon dioxide generated vascular endothelial growth factor encapsulated poly(dl-lactic acid) scaffolds induce angiogenesis in vitro. Biochem. Biophys. Res. Commun., v. 352, p. 135-141, 2007. https://doi.org/10.1016/j.bbrc.2006.10.187

KLAGSBRUN, M.; KNIGHTON, D.; FOLKMAN, J. Tumor angiogenesis activity in cells grown in tissue culture tumor angiogenesis activity in cells grown in tissue culture1. Cancer Res., v. 36, p. 110-114, 1976.

KOSCHÜTZKI, D.; LEHMANN, K.A.; PEETERS, L.; RICHTER, S.; TENFELDE-PODEHL, D.; ZLOTOWSKI, O. Centrality Indices, v. 16, p. 61, 2005. https://doi.org/10.1007/978-3-540-31955-9_3

KUE, C.S.; TAN, K.Y.; LAM, M.L.; LEE, H.B. Chick embryo chorioallantoic membrane (CAM): an alternative predictive model in acute toxicological studies for anti-cancer drugs. Exp. Anim., v. 64, p. 129-138, 2015. https://doi.org/10.1538/expanim.14-0059

KWAK, H.J.; PARK, M.J.; PARK, C.M.; MOON, S.I.; YOO, D.H.; LEE, H.C.; LEE, S.H.; KIM, M.S.; LEE, H.W.; SHIN, W.S.; PARK, I.C.; RHEE, C.H.; HONG, S. I.L. Emodin inhibits vascular endothelial growth factor-A-induced angiogenesis by blocking receptor-2 (KDR/Flk-1) phosphorylation. Int. J. Cancer, v. 118, p. 2711-2720, 2006. https://doi.org/10.1002/ijc.21641

LEE, S. ; BOZEMAN, B. The Impact of Research Collaboration on Scientific Productivity. Soc. Stud. Sci., v. 35, p. 673-702, 2005. https://doi.org/10.1177/0306312705052359

LOKMAN, N.A.; ELDER, A.S.F.; RICCIARDELLI, C.; OEHLER, M.K. Chick chorioallantoic membrane (CAM) assay as an in vivo model to study the effect of newly identified molecules on ovarian cancer invasion and metastasis. Int. J. Mol. Sci., v. 13, p. 9959-9970, 2012. https://doi.org/10.3390/ijms13089959

LV, X.; LING, L.; XIA, Y.; XU, Y.; HOU, F.; REN, J.; ZHANG, X.; LI, Y. Establishment of human hepatocellular carcinoma CAM xenograft model and observation of angiogenesis characteristics, v. 9, p. 3693-3698, 2016.

MORENO-JIMÉNEZ, I.; HULSART-BILLSTROM, G.; LANHAM, S.A.; JANECZEK, A.A.; KONTOULI, N.; KANCZLER, J.M.; EVANS, N.D.; OREFFO, R.O.C. The chorioallantoic membrane (CAM) assay for the study of human bone regeneration: A refinement animal model for tissue engineering. Sci. Rep., v. 6, p. 1-12, 2016. https://doi.org/10.1038/srep32168

NABOUT, J.; PARREIRA, M.R.; TERESA, F.B.; CARNEIRO, F.M.; DA CUNHA, H.F.; DE SOUZA ONDEI, L.; CARAMORI, S.S.; SOARES, T.N. Publish (In a group) or perish (alone): The trend from singleto multi-authorship in biological papers. Scientometrics, v. 102, p. 357-364, 2015.

https://doi.org/10.1007/s11192-014-1385-5 
NABOUT, J.C.; CARVALHO, P.; PRADO, M.U.; BORGES, P.P.; MACHADO, K.B.; HADDAD, K.B.; MICHELAN, T.S.; CUNHA, H.F.; SOARES, T.N. Trends and biases in global climate change literature. Nat. A Conserv., v. 10, p. 45-51, 2012. https://doi.org/10.4322/natcon.2012.008

NANSEN, C.; MEIKLE, W.G. Journal impact factors and the influence of age and number of citations. Mol. Plant Pathol., v. 15, p. 223-225, 2014. https://doi.org/10.1111/mpp.12096

NORRBY, K. In vivo. J Cell Mol Med, v. 10, p. 588-612, 2006. https://doi.org/10.2755/jcmm010.003.01

NOWAK-SLIWINSKA, P.; SEGURA, T.; IRUELA-ARISPE, M. The chicken chorioallantoic membrane model in biology, medicine and bioengineering. Angiogenesis, v. 17, n. 4, p. 779-804, 2014. doi:10.1007/s10456-014-9440-7.

R CORE, 2013 R Core Team A language and environment for statistical computing. R Foundation for Statistical Computing. Vienna, Austria. Available from: http://www.R-project.org/. 2013.

RIBATTI, D. The chick embryo chorioallantoic membrane (CAM). A multifaceted experimental model. Mech. Dev. v. 141, p. 70-77, 2016. https://doi.org/10.1016/j.mod.2016.05.003

RIBATTI, D. The chick embryo chorioallantoic membrane as a model for tumor biology. Exp Cell Res, v. 328, p. 314-324, 2014. https://doi.org/10.1016/j.yexcr.2014.06.010

RIBATTI, D. The chick embryo chorioallantoic membrane as an in vivo assay to study antiangiogenesis. Pharmaceuticals, v. 3, p. 482-513, 2010. https://doi.org/10.3390/ph3030482

RIBEIRO, S.S.; JESUS, A.M.; De ANJOS, C.S.; SILVA, T.B; SANTOS, A.D.C.; JESUS, J.R.; ANDRADE, M.S.; SAMPAIO, T.S.; GOMES, W.F.; ALVES, P.B.; CARVALHO, A.A.; PESSOA, C.; MORAES, M.O.; PINHEIRO, M.L.B.; PRATA, A.P.N.; BLANK, A.F.; SILVA-MANN, R.; MORAES, V.R.S.; COSTA, E. V.; NOGUEIRA, P.C.L.; BEZERRA, D.P. Evaluation of the Cytotoxic Activity of Some Brazilian Medicinal Plants. Planta Med., v. 78, p. 1601-1606, 2012.

ROVITHI, M.; AVAN, A.; FUNEL, N.; LEON, L.G.; GOMEZ, V.E.; WURDINGER, T.; GRIFFIOEN, A.W.; VERHEUL, H.M.W.; GIOVANNETTI, E. Development of bioluminescent chick chorioallantoic membrane (CAM) models for primary pancreatic cancer cells: A platform for drug testing. Sci. Rep. v. 7, p. 1-13, 2017. https://doi.org/10.1038/srep44686

SUBAUSTE, M.C.; KUPRIYANOVA, T.A.; CONN, E.M.; ARDI, V.C.; JAMES, P.; DERYUGINA, E.I. Evaluation of metastatic and angiogenic potentials of human colon carcinoma cells in chick embryo model systems. Clin Exp Metastasis, v. 26, p. 1033-1047, 2009. https://doi.org/10.1007/s10585-009-9293-4.

SUBRAMANYAM, K. Bibliometric studies of research collaboration: A review. J. Inf. Sci. v. 6, p. 33-38, 1983.

SUDAM PATIL, R.; UMESH SHAH, S.; VINAYAK SHRIKHANDE, S.; GOEL, M.; PRABHAKAR DIKSHIT, R.; VIVEK CHIPLUNKAR, S. IL17 producing $\gamma \delta$ T cells induce angiogenesis and are associated with poor survival in gallbladder cancer patients. Int. J. Cancer, v. 139, p. 869-881, 2016. https://doi.org/10.1002/ijc.30134

THANEKAR, D.; DHODI, J.; GAWALI, N.; RAJU, A.; DESHPANDE, P.; DEGANI, M.; JUVEKAR, A. Evaluation of antitumor and anti-angiogenic activity of bioactive compounds from Cinnamomum tamala: In vitro, in vivo and in silico approach. South African J. Bot. v. 104, p. 6-14, 2016.

https://doi.org/10.1016/j.sajb.2015.09.014 
WANG, C.; YAN,Q.; HU, M.M.; QUIN, D.; FENG, Z.Q. Effect of AURKA Gene expression knockdown on angiogenesis and tumorigenesis of human ovarian cancer cell lines. Targeted Oncol, v. 11, p. 11, 2016. doi:10.1007/s11523-016-0436-7

YAN, Y.; CHENG, X.; YANG, R.H.; LI, H.; CHEN, J.L.; MA, Z.L.; WANG, G.; CHUAI, M.; YANG, X. Exposure to excess phenobarbital negatively influences the osteogenesis of chick embryos. Front. Pharmacol. v. 7, p. 1-15, 2016. https://doi.org/10.3389/fphar.2016.00349

YEH, C.H.; WANG, W.C.; HSIEH, T.T.; HUANG, T.F. Agkistin, a snake venom-derived glycoprotein Ib antagonist, disrupts von Willebrand factor-endothelial cell interaction and inhibits angiogenesis. J Biol Chem v. 275, p. 18615-18618, 2000. doi: 10.1074/jbc.C000234200

YUAN, Y.J.; XU, K.; WU, W.; LUO, Q.; YU, J.L. Application of the chick embryo chorioallantoic membrane in neurosurgery disease. Int. J. Med. Sci. v. 11, p. 1275-1281, 2014. https://doi.org/10.7150/ijms.10443

ZHOU, X.; XU, C.J.; WANG, J.X.; DAI, T.; YE, Y.P.; CUI, Y.M.; LIAO, W.T.; WU, X.L.; OU, J.P. Metastasis-Associated in Colon Cancer-1 Associates With Poor Prognosis and Promotes Cell Invasion and Angiogenesis in Human Cervical Cancer. Int. J. Gynecol. Cancer v. 25, p. 1353-1363, 2015. https://doi.org/10.1097/IGC.0000000000000524 